\title{
ASEAN-5 Countries Stock Returns in Light with the Three-Fama and French Factor Model in Global Perspective
}

\author{
Hajanirina Andrianantenaina \\ hajanirina@president.ac.id \\ Accounting Study Program, Faculty of Business \\ Universitas Presiden, Cikarang, Indonesia
}

\begin{abstract}
This paper attempts to investigate the three factor model proposed by Fama and French (1993) upon the five country members within the Association of Southeast Asian Nations or simply ASEAN-5. Most of the studies on these countries deal with the cointegration or comovement of market stock returns. In overall, these markets are found cointegrated and break the boundaries amongst the cross-border. Besides, global interraction is also studied. Specific factors are not yet considered. Thus, global interaction is studied using the global three factor model. The samplesconsist of five countries global daily stock market index including Indonesia, Malaysia, Philippines, Singapore and Thailand from 2013 to2018. The result of this research shows a positive significant small minus law (SML) factors towards the global index for the case of Phillipines. Yet, other factors do not. Surprisingly, Indonesia, Malaysia, Singapore and Thailand are found insignificant towards the global factors.
\end{abstract}

Keywords: ASEAN-5, Three Factor Model of Fama and French, Global Stock Market Index, Abnormal Returns, Stock Market Returns, MSCI

\begin{abstract}
Abstrak
Paper ini mencoba menyelidiki model tiga faktor yang diusulkan oleh Fama dan French (1993) pada lima negara anggota Association of Southeast Asian Nations atau sering disebut ASEAN-5. Sebagian besar penelitian sebelumnya terhadap negara-negara ini sering berhubungan dengan kointegrasi atau co-movement dalam meneliti return pasar saham. Secara keseluruhan, pasar-pasar ini ditemukan terkointegrasi dan melampaui cross-borde. Selain itu, interraksi secara global juga sering dipelajari. Di lain sisi, faktor-faktor khusus belum dipertimbangkan. Oleh sebab itu, interaksi global dipelajari menggunakan model tiga faktor secara global. Sampel dalam studi ini terdiri dari lima negara dengan menggunakan indeks pasar saham harian global termasuk Indonesia, Malaysia, Filipina, Singapura dan Thailand dari 2013 hingga 2018. Hasil penelitian ini menunjukkan bahwa faktor small minus law (SML) signifikan dan positif terhadap indeks global untuk kasus Filipina. Akan tetapi, faktor-faktor lain tidak. Untuk Indonesia, Malaysia, Singapura dan Thailand ditemukan tidak signifikan terhadap faktor-faktor tersebut secara global.
\end{abstract}

Kata Kunci: ASEAN-5, Model Tiga Factor Model oleh Fama dan French, Pasar Saham Global Indeks Pasar Saham, Abnormal Returns, Return Pasar Saham, MSCI 


\section{INTRODUCTION}

Globally, the Association of Southeast Asian Nations(ASEAN) is connected to the rest of the world in terms of social, politic and economic environment. Most of the studies for the ASEAN community focuse on cointegration, spillover, contangion and comovement in terms of stock market returns and suggest that the relationship occurs during the period of observation (pre, during and post Asian crisis of 1997-1998) ((Chen et al (2009), Balli et al.(2014), Chien et al. (2015), Click and Plummer (2005)). Thus, daily and weekly returns are used to test for the cointegration existence among the ASEAN-5. In this study, ASEAN-5 are represented by the original members including Indonesia, Malaysia, Philippines, Singapore and Thailand. Found that, by using the three types of structural break, these markets are highly integrated. Apart from that, while diversifying the investment, the risk reduction tends to be not as profitable as expected. Besides, Asian financial crises of 1997-1998 impact on the structural break estimation. Amongst the five countries, Singapore leads as financial center of the community.In long term horizon, Singapore and Thailand are those that drive the market if Indonesia and Malaysia do for the short term (Chen et al, 2009).

The ASEAN community convey the idea of emerging stock market for the Southeast Asian part. Similarly to the case of some Arabic countries including Kuwait, Saudi Arabia and Bahrain, global integration is found. Al-Deehani and Moosa (2006) suggest that even if one market volatility could not be the cause of the other markets', yet, the relationship on some countries are related to one another. For the case of three countries including Saudi Arabia, Kuwait and Bahrain, influence is detected amongst these three markets. Kuwait markets impact strongly on both Bahrain and Saudi Arabia. The latter has strong relationship to Kuwait's but not for Bahrain, but Bahrain only impacts on Kuwait. The main cause is then the increase in integration among these countries. Apart form that, durability of the markets like Kuwait's primes over the younger markets. All impacts could not be with a single explanation, though.

All of these countries go global in terms of stock market. Most of the studies in terms of stock return for the three factors, four factors, five factors, CAPM, or any other single model study the returns on corporate level. Susanti (2013), found that the three factors impact on the Indonesia stock market returns. The single factor is then limited for that quest as size and book-to-market have significant values. Yet, the study focuses on only 45 firms most liquid in Indonesia. Besides, the period lags nine years ago (2005-2009). However, the ASEAN community has open the market worldwide. Besides, US influence on the global market including these five countries from the currency, multinational firms that are established within these countries. For instance, Yang and Hamori (2014) examine the US monetary policy to ASEAN countries but only three members of them are studied including Indonesia, Singapore and Thailand. They find that the spill over exists over the markets during financial crisis but during normal period the negative effect fades away. It is so as the cause is only for the transmission mechanism.

Globally, contangion and spillover effects exist over many countries from global influences. Among of them the US influence and Asian trace where ASEAN countries are also part of. For Indonesia as an example, the depreciation of rupiah against dollar has significant impact on its economic variables. Thus, global perspective for the ASEAN countries is necessary while considering the market stock returns. 


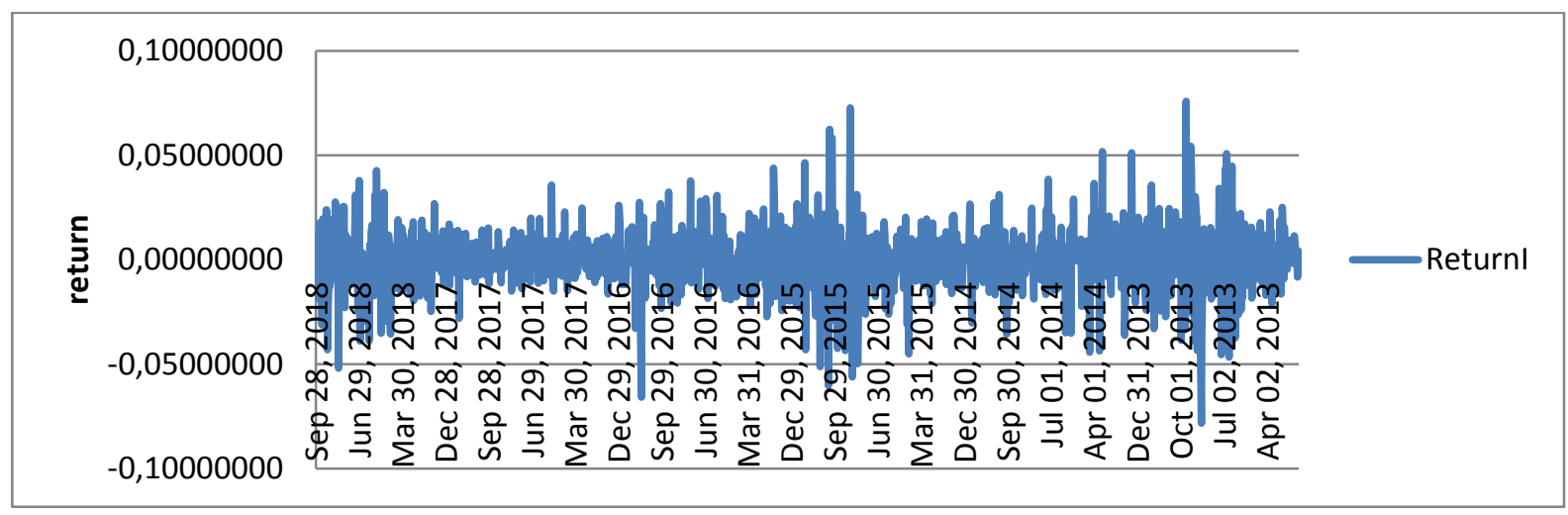

Figure 1. Indonesian Stock Market Return Source: Data Processed

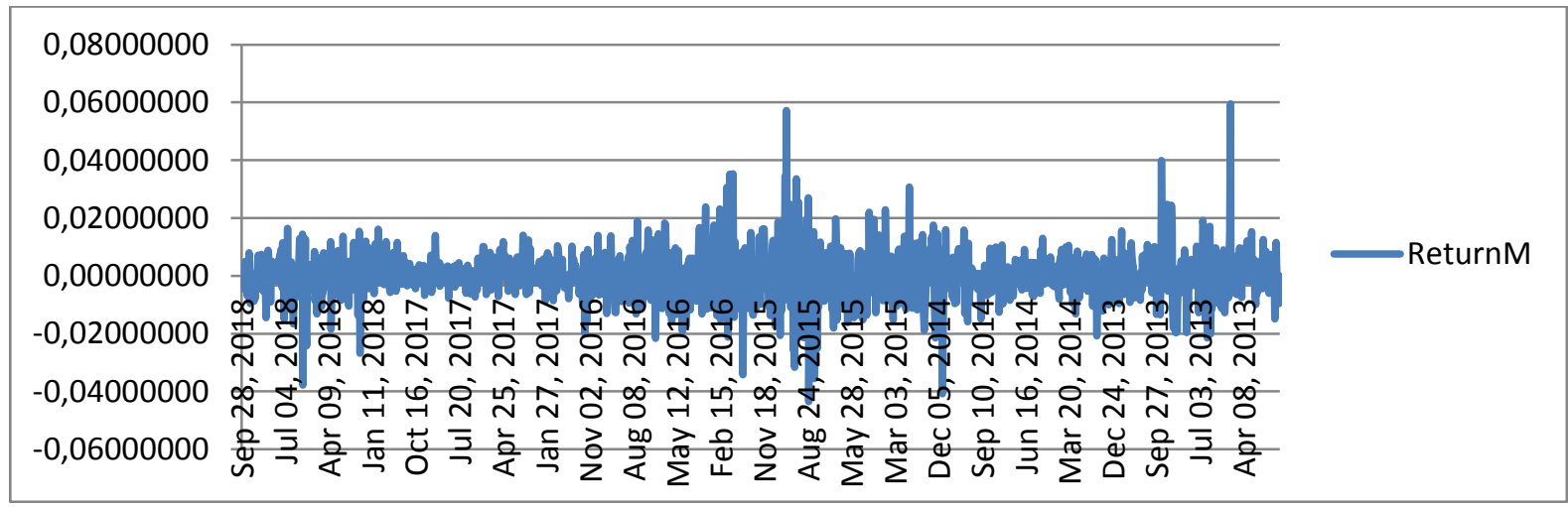

Figure 2. Malaysian Stock Market Return

Source: Data Processed

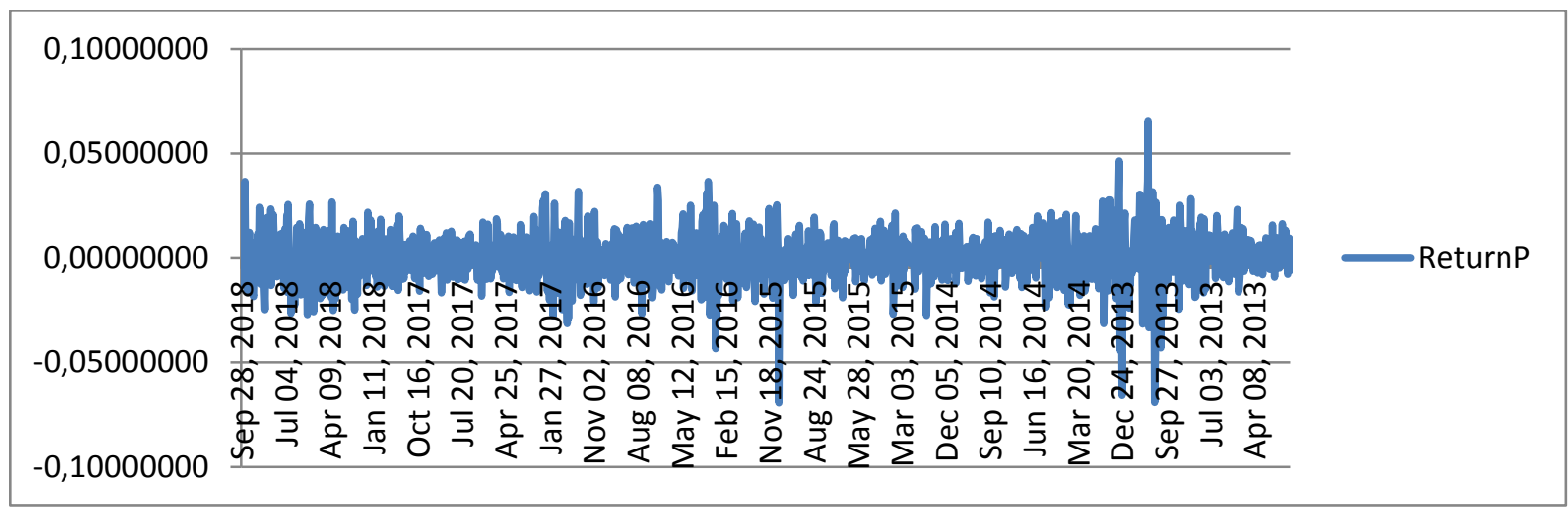

Figure 3. Philippian Stock Market Return

Source: Data Processed

These returns for the first three countries including Indonesian, Malaysian as well as Philippines share the same characteristics of having constant variance. It implies these stocks might probably impacted from global factors and the impact might be similar. Thus, analysis is needed to detect that impact on these stocks. 


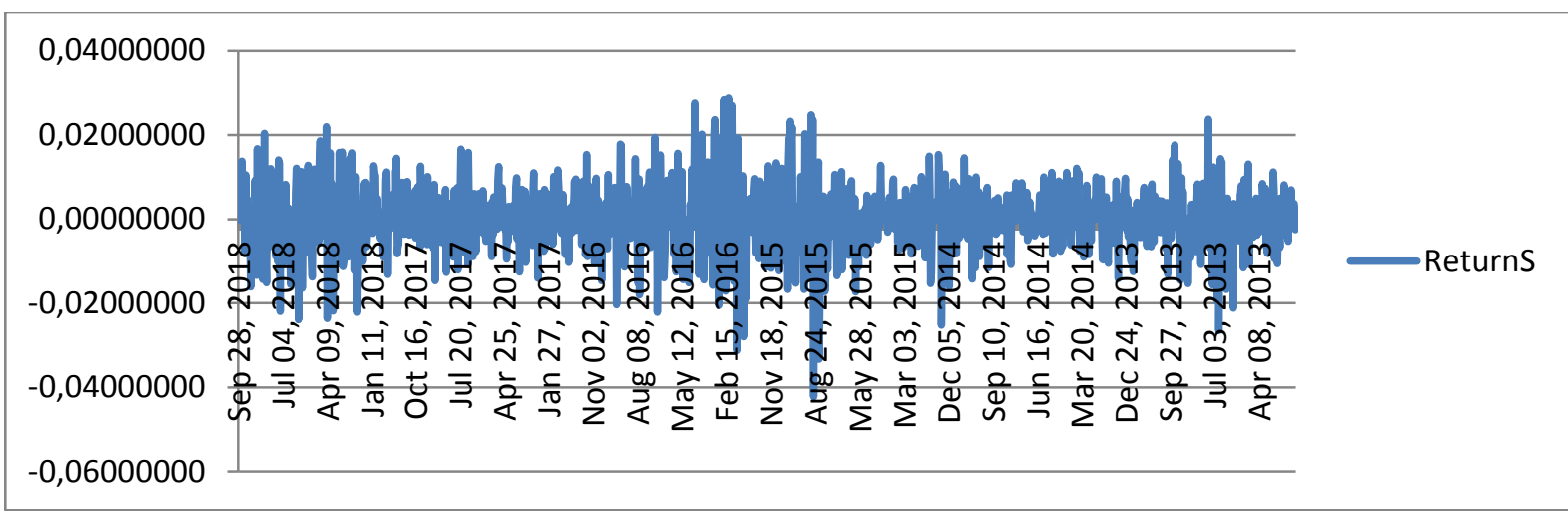

Figure 4. Singaporean Stock Market Return Source: Data Processed

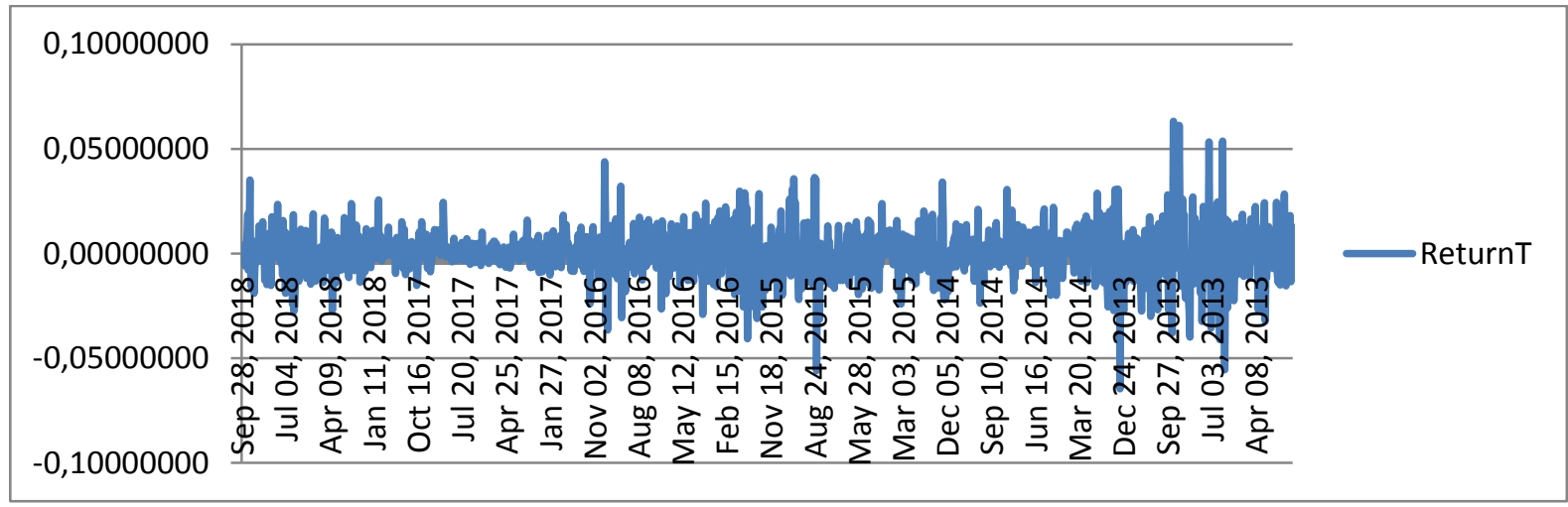

Figure 5. Thailand Stock Market Return

Source: Data Processed

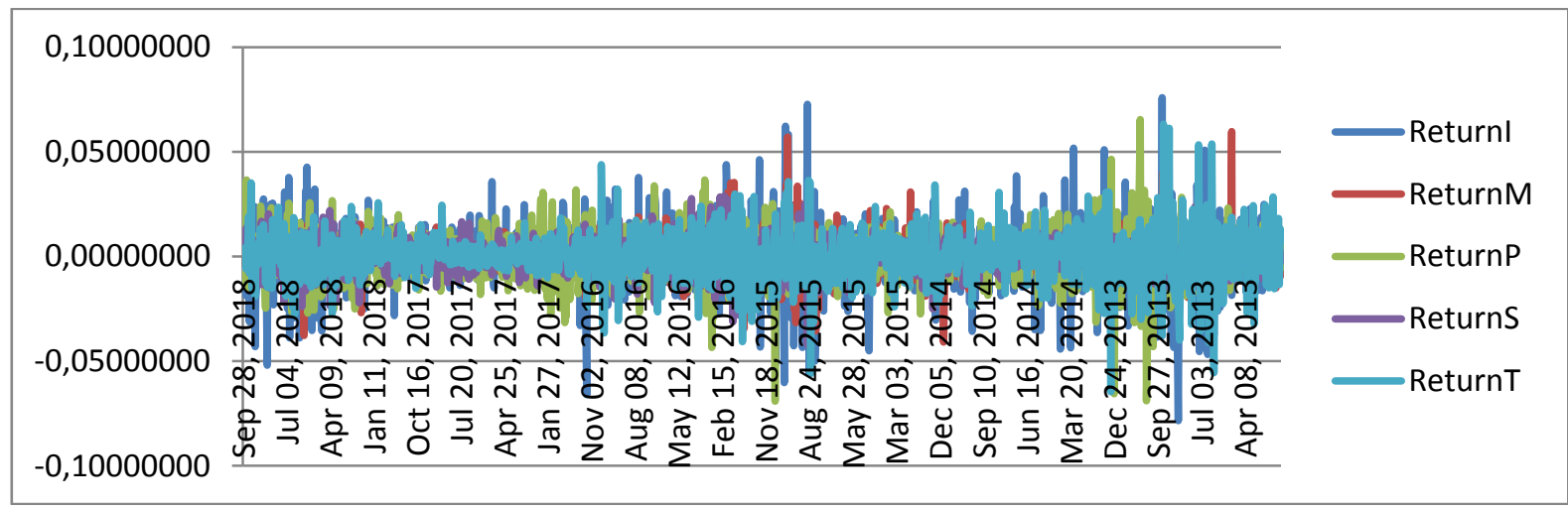

Figure 6. ASEAN-5 Stock Market Return

Source: Data Processed

As shown on Figure 4 and 5, Singaporean stock returns are more volatile than those of Thailand. However, they share the same types of having constant variance. Figure 1 to 5 show widely that characteristics. Besides, Figure 6 indicates that these stock markets similarly contain a constant variance. The volatility does not highly vary accross the period. Thus, does, global index of these ASEAN-5 countries has relationship to global factors? This querry is important to test for the return analysis using Fama and French (1993). Besides, for the standard deviation for all stocks, Table 1 shows the deviation of the data that have lower level of dispersion from the mean. It has relationship with the result that the return is not as high as expected (high risk with high return) but low risk with low return. 


\section{LITERATURE REVIEW}

\section{Global Market Index and ASEAN}

ASEAN emerging markets are characterized by high volatility. The study examines emerging markets based on important events (crisis), and socio-economic and political factors. The period is (1985-1995) already long time ago. It suggests that country specific events impact on the volatility like the conflict in the Philippines. Besides, it is found that daily change of stock market returns often occurs than those of weekly or monthly (Aggarwalet al., 1999). These markets cointegrate one another within the community as well as to the rest of the world. Within the community, regulation is needed. Ahmed and Sundararajan (2009), investigate that since the Asian crisis started from 1997 to 1998, ASEAN economic cooperation and integration was empowered. ASEAN-5 are composed of Indonesia, Malaysia, Philippines, Singapore and Thailand. Some problems emerge on the integration, for instance the inexistance of derivative markets. Besides, cross-border regulations need to be clear. Found that private stock market exchanges have been emphasized and the public also is important, but the application is still critical. Regulations on billateral and multilateral stock market exchange are key success of this ASEAN countries cooperation and integration.

Asian continent impacts on the ASEAN community including the emerging countries like China, South Korea, India and others. Asian financial crisis of 1997-1998 is one of the cause when countries suffer from financial difficulties (Chen et al, 2009).The relationship among these five countries on the ASEAN-5 is observed. Furthermore, China is added to test the impact of global factor towards these countries. Found that, the level of cointegration amongst these countries including China has an increasing significant trend. Specifically, the adjustment lies on the case of China and Indonesia if the others do not share the same point. It enhances the global impact of this five countries towards the rest of the world including the Asian countries (Chien et al., 2015). Thus the first hypothesis is formulated as bellow.

\section{Hypothesis 1: GlobalAsian factors impacton the ASEAN-5 Market stock returns}

The results on global market returns still provide for different findings. It could be compared from local to global shock that make the returns varied. For that, Local and global shocks are studied towards the ASEAN stock markets. For Singapore and Vietnam, their stock returns are not caused by the global shock but national wide only. The global and local spillover effect decreases for the ASEAN stock sectors' indices. As the study focuses on the sectors, the spillover effect has positive significant over food and beverage as well as industry group. This study also suggests that for a better concern, portfolio for ASEAN national returns prime over ASEAN-wide ones for investors (Balli et al., 2014). The case is for Singapore and Vietnam only. Global index factors might have significant impact on the community. Somehow, US influence is important due to its currency and all the political and economical dominance. Effect on spillover for instance impacts during the financial crisis Yang and Hamori (2014). Thus, two other hypotheses need to be tested.

Hypothesis 2: Global factors impact on the ASEAN-5 Market stock returns Hypothesis 3: US factors impact on the ASEAN-5 Market stock returns

These hypotheses imply on the main objective of these research. Some control and evidence are studied as well in order to enhance the relationship among the returns and the global index. 


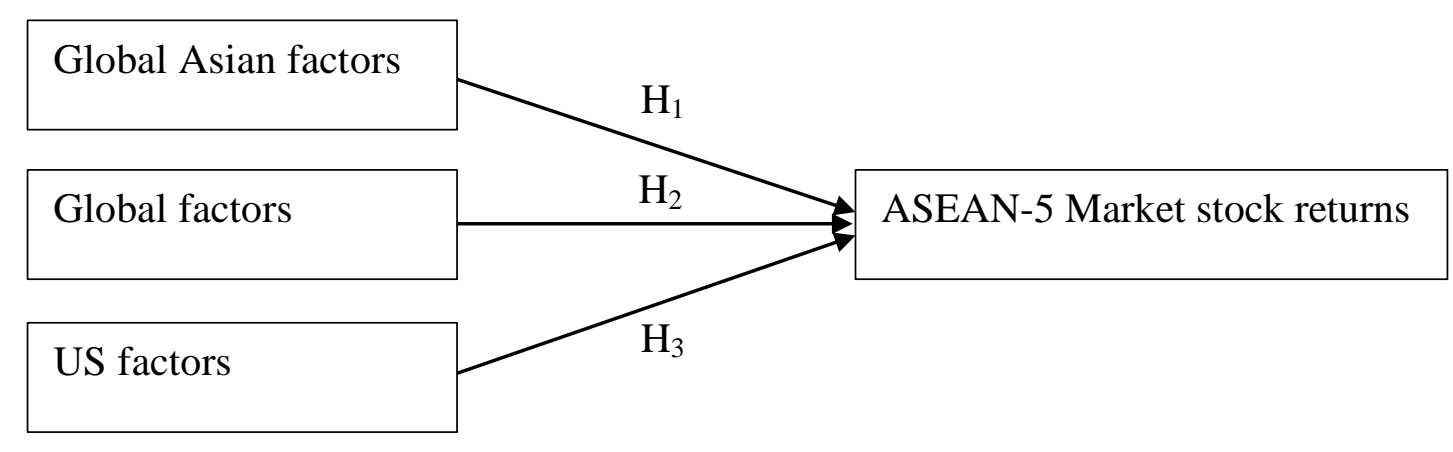

Figure 7. Research Framework

Source: Literature Review

From this framework, direct relationships are then tested. These hypotheses are then tested respectively, the variables convery the detailed test made.

\section{RESEARCH METHOD}

In this research global stock prices are used to estimate the stock market returns. These secondary data are sourced from MSCI global index. This is so to use similar data in the global perspective (expressed all in USD) not on regional basis with local currency. Apart from that, the three factors are provided as well to investigate the relationship while varying the composite from the international perspectives. The period of observation starts from 2013 to 2018 using daily stock prices. Due to the availability of the data, only five countries from the Association of Southeast Asian Nations or simply ASEAN-5 are considered.

The followings are then the estimation model:

$$
\begin{gathered}
M R_{1 t}=\alpha_{1 t}+\beta_{1 t}(M k t-R f)_{1 t}+\beta_{2 t} S M B_{1 t}+\beta_{3 t} H M L_{1 t}+\beta_{4 t-1}(M k t-1-R f)_{1 t-1}+\beta_{5 t-1} S M B_{1 t-1}+\beta_{6 t-} \\
(1) \\
{ }_{1} H M L_{1 t-1}+\varepsilon_{1} \\
M R_{2 t} M R_{1 t}=\alpha_{2 t}+\beta_{7 t}(M k t-R f)_{1 t}+\beta_{8 t} S M B_{1 t}+\beta_{9 t} H M L_{1 t}+\beta_{10 t-1}(M k t-1-R f)_{1 t-1}+\beta_{11 t-1} S M B_{1 t-1} \\
+\beta_{12 t-1} H M L_{1 t-1}+\varepsilon_{2} \\
M R_{3 t}=\alpha_{3 t}+\beta_{13 t}(M k t-R f)_{1 t}+\beta_{14 t} S M B_{1 t}+\beta_{15 t} H M L_{1 t}+\beta_{16 t-1}(M k t-1-R f)_{1 t-1}+\beta_{17 t-1} S M B_{1 t-1}+ \\
\quad \beta_{18 t-1} H M L_{1 t-1}+\varepsilon_{3} \\
M R_{4 t}=\alpha_{4 t}+\beta_{19 t}(M k t-R f)_{1 t}+\beta_{20 t} S M B_{1 t}+\beta_{21 t} H M L_{1 t}+\beta_{22 t-1}(M k t-1-R f)_{1 t-1}+\beta_{23 t-1} S M B_{1 t-1}+ \\
\beta_{24 t-1} H M L_{1 t-1}+\varepsilon_{4}
\end{gathered}
$$

Where:

MR : Market abnormal return, 1: using global index; 2: for Pacific Asian global factor of Fama and French index, 3: for US index

Mkt-Rf : Market return in light with the risk free, 1: using global index; 2: for Pacific Asian index, 3: for US index

SMB : Small minus big (cap), 1: using global index; 2: for Pacific Asian global factor of Fama and Frenchindex, 3: forUS index

HML : High minus low (cap)., 1: using global index; 2: for Pacific Asian global factor of Fama and French, 3: for US index 
The dependent variable includes MR as abnormal return. Thre three independent variables or the three factors are then the rest which are Market return in light with the risk free, Small minus big (cap), and High minus low (cap).

For the weight, the following is used:

$S M B_{B / M} X=13($ HighSmallX + NeutralSmallX + LowSmallX $)-13($ HighBigX +

NeutralBigX+LowBigX)

$H M L=1 / 2($ Small Value + Big Value $)-1 / 2($ Small Growth + Big Growth $)$

\section{RESULTS AND DISCUSSION}

\section{Descriptive Analysis}

The following table describes the market returns and the three factors in this study.

Table 1. Abnormal Return and the Three Factors

\begin{tabular}{llllll} 
Variable & Obs. & Mean & Std. Dev. & Min & Max \\
\hline AR1I & 1478 & 0.0000325 & 0.0142127 & -0.0784006 & 0.0758174 \\
AR2I & 1478 & 0.0000325 & 0.0142127 & -0.0784006 & 0.0758174 \\
AR3I & 1478 & 0.0000325 & 0.0142127 & -0.0784006 & 0.0758174 \\
AR3I & 1478 & 0.0000325 & 0.0142127 & -0.0784006 & 0.0758174 \\
AR1M & 1478 & -0.0000113 & 0.0083536 & -0.0435474 & 0.0595334 \\
AR2M & 1478 & -0.0000113 & 0.0083536 & -0.0435474 & 0.0595334 \\
AR3M & 1478 & -0.0000113 & 0.0083536 & -0.0435474 & 0.0595334 \\
AR4M & 1478 & -0.0000173 & 0.0083529 & -0.0435474 & 0.0595234 \\
AR1P & 1478 & 0.0003117 & 0.0111171 & -0.0691965 & 0.0653548 \\
AR1P & 1478 & 0.0003117 & 0.0111171 & -0.0691965 & 0.0653548 \\
AR2P & 1478 & 0.0003117 & 0.0111171 & -0.0691965 & 0.0653548 \\
AR3P & 1478 & 0.0003117 & 0.0111171 & -0.0691965 & 0.0653548 \\
AR1S & 1478 & 0.0000320 & 0.0074207 & -0.0421654 & 0.0287533 \\
AR1S & 1478 & 0.0000320 & 0.0074207 & -0.0421654 & 0.0287533 \\
AR3S & 1478 & 0.0000320 & 0.0074207 & -0.0421654 & 0.0287533 \\
AR4S & 1478 & 0.0000259 & 0.0074197 & -0.0421654 & 0.0287533 \\
AR1T & 1478 & 0.0002311 & 0.0111876 & -0.0646448 & 0.0632009 \\
AR2T & 1478 & 0.0002311 & 0.0111876 & -0.0646448 & 0.0632009 \\
AR3T & 1478 & 0.0002311 & 0.0111876 & -0.0646448 & 0.0632009 \\
AR4T & 1478 & 0.0002250 & 0.0111869 & -0.0646448 & 0.0632009 \\
MktRFg & 1478 & 0.0004288 & 0.0064398 & $(0.051100)$ & 0.0239000 \\
SMBg & 1478 & 0.0000373 & 0.0032532 & $(0.019400)$ & 0.0147000 \\
HMLg & 1478 & -0.0000491 & 0.0030522 & $(0.012000)$ & 0.0158000 \\
MktRFgus & 1478 & 0.0003217 & 0.007029 & $(0.065700)$ & 0.0293000 \\
SMBgus & 1478 & 0.0001024 & 0.0040166 & $(0.021300)$ & 0.0273000 \\
HMLgus & 1478 & 0.0000218 & 0.0029527 & $(0.010700)$ & 0.0132000 \\
MktRfap & 1478 & 0.0001966 & 0.0072614 & $(0.056600)$ & 0.0279000 \\
\hline & & & & &
\end{tabular}




\begin{tabular}{llllll}
\hline SMBap & 1478 & -0.0001016 & 0.0045076 & $(0.035700)$ & 0.0503000 \\
HMLap & 1478 & 0.0002404 & 0.0040239 & $(0.014800)$ & 0.0178000 \\
MktRfus & 1478 & 0.0005587 & 0.0079169 & $(0.040300)$ & 0.0368000 \\
SMBus & 1478 & 0.000027 & 0.0048879 & $(0.016600)$ & 0.025000 \\
HMLus & 1478 & -0.0000289 & 0.0046547 & $(0.016900)$ & 0.0238000 \\
\hline
\end{tabular}

Source: Data processed

All the minimum values are negative, that means that loss might be gained possible however the rate of return is as well as high. The standard deviation does not really high compared to its mean. Thus, the excess return or loss might not be huge. 

Table 2. Result of the Global Relationship 1

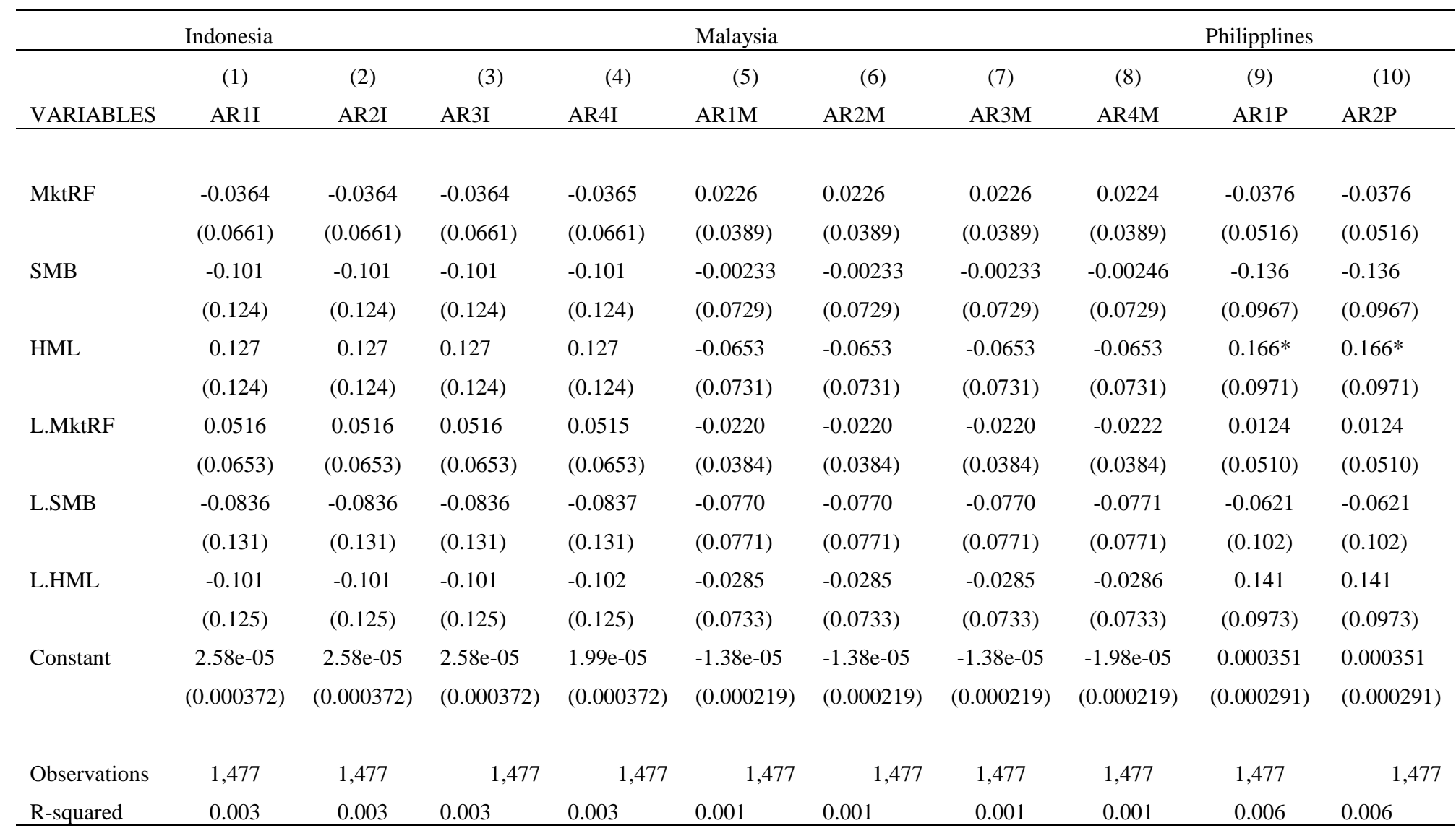

Standard errors in parentheses

*** $\mathrm{p}<0.01, * * \mathrm{p}<0.05, * \mathrm{p}<0.1$ 
From this research (Table 2 and Table 3), among the ASIAN-5 countries, the result is surprisingly interesting. Using lag difference of a year, the relationship is somehowinsignificant.Controlling for the impact that might be caused during the periodical event within the year of study, the lag is variables seem not supported.

The Phillipines demonstrates a positive significant relationship towards the global market. The high minus low factor shows that relationship. It indicates that the difference is important for a market by which it tends to be active within the emerging area. This result traces the range of market that is in relationship with the Asian, US and the rest of the world. This country is considered as emerging market, even if not the first leading for the ASEAN region (lag behind Singapore for instance), its market is subject of the sudden change of the price of the stock not the traded size. The small value of R-square is due to the fact that the three factors have limitation. However, this research does not include the other factors as studied for other papers. The objective remains on the analysis of the three factors only. 
Table 3. Result of the Global Relationship (continued)

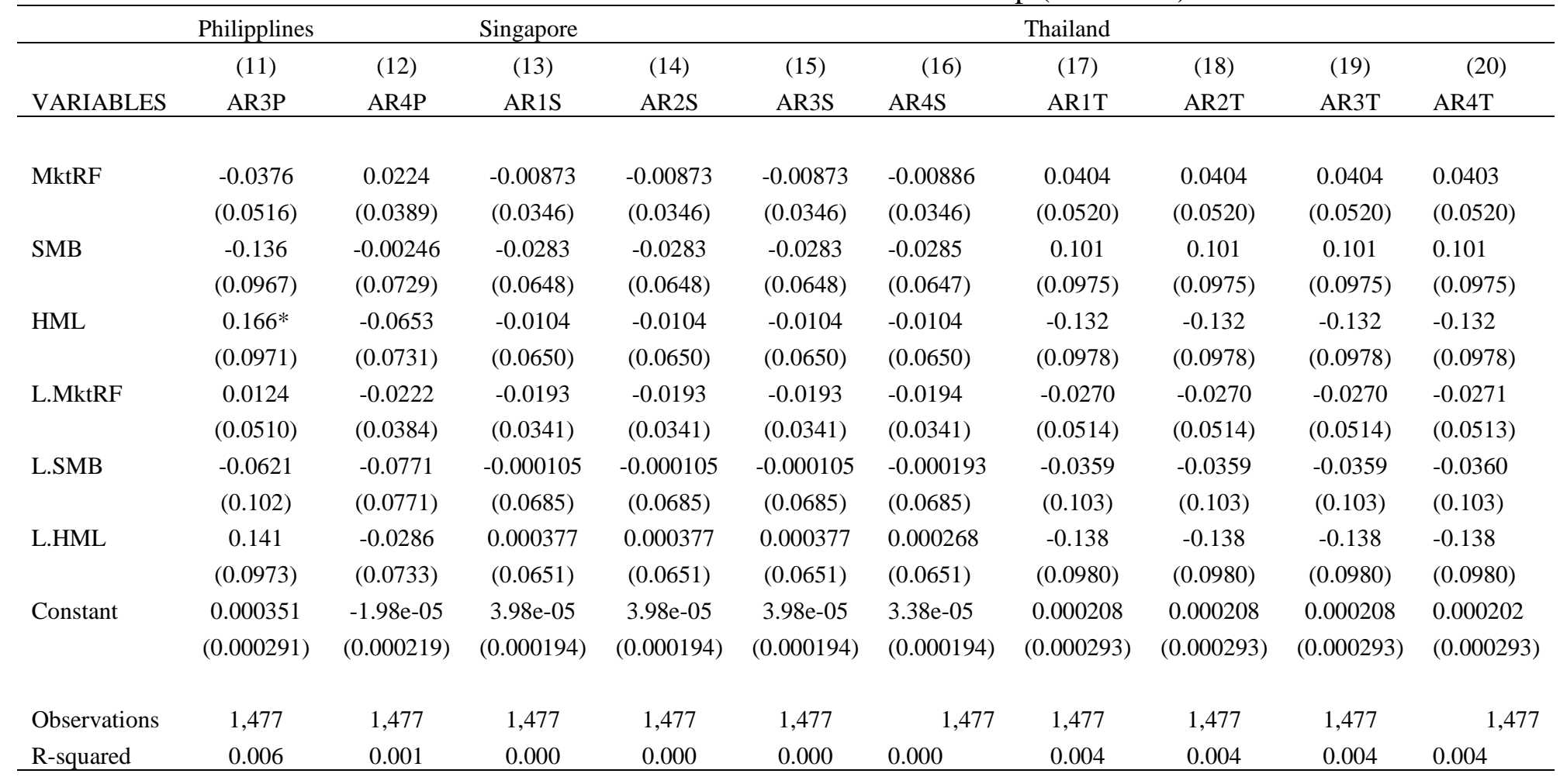

Standard errors in parentheses

$* * * \mathrm{p}<0.01, * * \mathrm{p}<0.05, * \mathrm{p}<0.1$ 
For the case of Indonesia, Malaysia, Singapore and Thailand; the global factors, Asian and US factors are not found related. This result is not in line with Chen et al, (2009), Chien et al. (2015) and Balli et al. (2014) in terms of market integration. Based on the three factor model proposed by Fama and French (1993), the factors for global extension is not supported for in this study. It is might due to the fact that these stocks are still classified as peny stock by which the price is still lower than those in the US and other developed markets.

\section{CONCLUSION}

In the global context, the three factors need to be analysed relatively towards the country in consideration. Global index might not be applicable for global factors. Country level analysis is important to be analysed as it might show the relationship among the markets in a given economic community. For the case of ASEAN-5, it is found that the markets are diverse depending on the their state (position, duration and the environment by which the citizen participate or not). Fama and French's factors need to be adapted to trace the country specific condition. The Phillippines show positive relationship towards the global factors as the market condition is relatively emergent. The rest including, Indonesia, Malaysia, Singapore and Thailand, the global impact using the factors is not significant. This study only consider the effect of global index without building global factors, it only consider the secondary data on the factors that might limit the country specific conditions. Further study on global index and global factors that consider the country specific market conditions is encouraged. Besides, for the R-square value, it is advisable for future research to consider all the factors that are prominent for this study. Thus, considering the five factors or others might be feasible.

\section{REFERENCES}

Aggarwal, R., Inclan, C., \& Leal, R. (1999). Volatility in Emerging Stock Markets. The Journal of Financial and Quantitative Analysis, 34(1), 33-55.

Ahmed, J., \& Sundararajan, V. (2009). Regional Integration of Capital Markets in ASEAN: Recent Developments, Issues, and Strategies (with Special Reference to Equity Markets). Global Journal of Emerging Market Economies, 1(1), 87-122.

Al-Deehani, T., \& Moosa, I. A. (2006). Volatility Spillover in Regional Emerging Stock Markets: A Structural Time-Series Approach. Emerging Markets Finance \& Trade, 42(4), 78-89.

Balli, F., Balli, H. O., \& Luu, M. N. (2014). Diversification across ASEAN-wide Sectoral and National Equity Returns. Economic Modelling, 41, 398-407.

Chen, C. W., Gerlach, R., Cheng, N. Y., \& Yang, Y. (2009). The Impact of Structural Breaks on the Integration of the ASEAN-5 Stock Markets. Mathematics and Computers in Simulation, 79, 2654-2664.

Chien, M.-S., Lee, C.-C., \& Hu, H.-T. (2015). Dynamic Asian Stock Market Convergence: Evidence from Dynamic Cointegration Analysis among China and ASEAN-5. Economic Modelling, 51, 84-98.

Click, R. W., \& Plummer, M. G. (2005). Stock Market Integration in ASEAN after the Asian Financial Crisis. Journal of Asian Economics, 16, 5-28.

Fama, E. F., \& French, K. R. (1993). Common Risk Factors in the Returns on Stocks and Bonds. Journal of Financial Economics, 33, 3-56. 
Susanti, N. (2013). Pengujian Fama French Three Factor Model pada Perusahaan di Indonesia yang Sahamnya terdapat di LQ 45 Tahun 2005-2009. Forum Keuangan \& Bisnis II, 535-559.

Yang, L., \& Hamori, S. (2014). Spillover Effect of US Monetary Policy to ASEAN Stock Markets: Evidence from Indonesia, Singapore, and Thailand. Pacific-Basin Finance Journal, 26, 145-155. 